\title{
Discrepancy in perception of infertility and attitude towards treatment options: Indonesian urban and rural area
}

\author{
Achmad Kemal Harzif, Victor Prana Andika Santawi ${ }^{*}$ and Stephanie Wijaya
}

\begin{abstract}
Background: In Indonesia infertility affects $10-15 \%$ of reproductive-age couples. In addition to medical problem, infertility in Indonesia poses significant social problem. Childlessness is often stigmatized as a failure which victimizes couples, moreover the females. Despite the high prevalence, there is no fertility awareness education which further passes down the common myth, misperception, and negative attitude towards infertility treatment in Indonesian society.

Objective: This study aims to reveal the knowledge, myth, and attitude towards infertility, likewise acceptance towards infertility treatment options.

Method: Cross-sectional study using standardized questionnaire was done to 272 individuals consisted of two parallel groups: Jakarta and Sumba representing urban and rural population respectively. Participants were all outpatients above 18 years old who visited the healthcare centers from February 2017 to June 2017.

Results: Knowledge on biological and lifestyle risk factors of infertility among Jakarta and Sumba groups were comparable. However, belief in supernatural causes of infertility is remarkable in Sumba population. There is a common misconception on the use of contraception as risk factors of infertility in both groups.

Half respondents from both groups think infertility is a disease. In Jakarta 93.4\% respondents consider both female and male should be investigated for infertility; in Sumba only 55.4\% agree while 33.1\% consider only female should be investigated. Infertility is an acceptable reason for polygamy for $41.3 \%$ respondents in Sumba, with $34.7 \%$ blaming maternal side for childlessness.

Most respondents from both groups accept the use of Assisted Reproductive Technology and fertility enhancing drugs as treatment options.
\end{abstract}

Conclusion: Lack of understanding, misleading myths, and negative attitude towards infertility have been illustrated in the sample population.

Keywords: Infertility, Urban, Rural, Knowledge, Myth, Attitude, Misperception, Assisted reproductive technology

\section{Plain English summary}

Infertility is defined as inability to conceive after 1 year of regular unprotected sexual intercourse. As a disease, many treatment efforts have been suggested. However, infertility has a strong social impact in the culturally and socioeconomically diverse Indonesia. This study attempts

\footnotetext{
* Correspondence: vsantawi@gmail.com

Department of Obstetrics and Gynecology, Universitas Indonesia, Cipto Mangunkusumo National Hospital, Jl. Pangeran Diponegoro no. 71. Kenari, Senen, Kota Jakarta Pusat, Daerah Khusus Ibukota Jakarta, Jakarta 10430, Indonesia
}

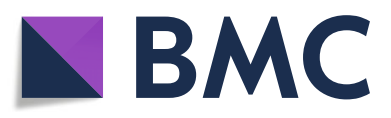

(c) The Author(s). 2019 Open Access This article is distributed under the terms of the Creative Commons Attribution 4.0 International License (http://creativecommons.org/licenses/by/4.0/), which permits unrestricted use, distribution, and reproduction in any medium, provided you give appropriate credit to the original author(s) and the source, provide a link to the Creative Commons license, and indicate if changes were made. The Creative Commons Public Domain Dedication waiver (http://creativecommons.org/publicdomain/zero/1.0/) applies to the data made available in this article, unless otherwise stated.

to compare the perception of infertility from participants living in two different societies: urban and rural area.

The local participants who grew up in urban (151 participants) and rural area (121 participants) were interviewed using questionnaires individually. The participants from these two locations has a different demographic profile.

It was found that regardless of their difference level of education, they have poor knowledge regarding infertility and what are the risk factors. Half of participants in Indonesian rural area still believe that black magic and mythical reasons are the root for infertility. It is also 
interesting to highlight that regardless of difference in religion and cultural background, participants from both areas tend to victimize women for infertility. It was found that in both societies, it is more acceptable for the husbands to divorce or remarry due to infertile wife than for the wives to divorce or remarry due to infertile husband.

In conclusion, similar views towards infertility and its treatment option can be observed. Devastating social outcome such as divorce is often deemed acceptable in infertile couple for urban and rural society in Indonesia.

\section{Background}

Infertility is classified as a disease by the World Health Organization, thus considered as a condition that should be treated [1]. Medical professionals deem intervention is necessary towards infertile couple due to high burden it causes towards infertile couples, especially for women. Primary infertility is defined as inability to conceive after 1 year of unprotected sexual intercourse with no previous conception. Secondary infertility is the condition where a couple has conceived previously but became unable then.

Infertility is prevalent, affecting 80 million couples of reproductive age worldwide. In Indonesia, the number translates to $21.3 \%$ of couples, affecting roughly one in every couple [2]. Stratified medical approach has been established in Indonesia, however its application is poorly evaluated. Fortunately, $90 \%$ of infertility cases have an identifiable cause and half will result in pregnancy given the proper treatment [3].

Infertility poses not only as medical problem, but also a social stigma. Several studies have demonstrated the notorious effect of infertility from social point of views [4-6], There is no formal education in Indonesia regarding infertility. This perpetuates passing down of perception towards infertility, including myths, misinformation, and negative attitudes.

Known modifiable risk factors have been well reviewed, with equal contributing factors from each gender [7]. Whether this knowledge has been well distributed in the population remains a mystery. Indonesia is a multi-cultural country with societies having different religious beliefs, education, social and economic background. Infrastructures also differ by a big margin depending on where the societies are geographically located. Availability of facilities and technological difference ultimately would lead to different accessibility of information.

This study hopes to compare and contrast between participants from urban and rural area of Indonesia. The study sought the level of knowledge regarding infertility, attitude towards infertility, social impact of infertility, and attitude towards infertility treatment options.

\section{Methods}

\section{Site and study design}

Two cross sectional surveys were conducted among conveniently sampled individuals above 18 years old. In Jakarta, the first survey was conducted in primary care center in Pasar Rebo, Pekayon, Indonesia (Puskesmas Kecamatan Pasar Rebo) and in tertiary care hospital in Senen, Jakarta, Indonesia (Rumah Sakit Cipto Mangunkusumo). In East Sumba, the second survey was conducted in primary care center in Waingapu, East Sumba, Indonesia (Puskesmas Kota Waingapu). These centers were selected because they were visited by individuals from various social-economic, education and ethnic backgrounds, and thus provide closer representation of the general population.

\section{Recruitment and interview}

All the outpatients who visited the respective healthcare centers from February 2017 to June 2017 and willing to participate were interviewed in private by their own respecting General Practitioners. Informed consent was asked before each interview. Questionnaire forms were filled in by interviewer based on the respondents' answer. In Sumba, due to some difficulties in understanding Bahasa Indonesia, some outpatients were omitted from the interview.

\section{Questionnaire}

The questionnaire used was based on previously published literature on infertility $[4,8,9]$. Any language and contextual modification to fit local beliefs were previously consulted to obstetrics and gynecology consultant.

The questionnaires were translated to be written in Bahasa Indonesia, the national language of Indonesia. The terms used were meticulously chosen according to the national dictionary to facilitate comprehension of the questions. Each interviewer has been trained by the authors to equalize the meaning of the questions and its implication.

\section{Data management}

The data was entered to Microsoft Excel 2016 and then imported by SPSS IBM v23 for statistical management.

\section{Ethical consideration}

This study been reviewed and given ethical approval from Ethics Committee of the Faculty of Medicine, Universitas Indonesia (ethical approval protocol number: 0634/UN2.F1/ETIK). All subjects had the right to withdraw from the study anytime they wished without giving any explanation. The questionnaire was anonymous and ensured confidentiality of the study participants. Informed consent was obtained from each participant prior to the interview. 


\section{Results}

\section{Demographic profile}

Based on a total sample of 272 individuals interviewed (151 in Jakarta and 121 in East Sumba), the difference in demography could be illustrated. Roughly equal male and female participants were included in both places (mean of $43.1 \%$ males and $56.9 \%$ females). Mean age was younger in Jakarta participants compared to East Sumba $(25.5 \pm 6.1$ years-old vs. $37.6 \pm 12.3$ years-old $)$ and most participants in Jakarta were unmarried (76.8\% vs. $13.2 \%)$. Despite the younger age, formal educational level was much higher in Jakarta $(98.7 \%$ vs. $55.4 \%$ has finished high school). The major religion in each area were also different: $75.5 \%$ of Muslims in Jakarta and $69.4 \%$ of Christians or Catholics in East Sumba. Table 1 shows the summary of demographic profile.

\section{Knowledge of infertility}

The question regarding knowledge of the participants preceded by the definition of infertility. None of the participants in both areas could correctly define infertility as inability of conceive after 1 year of unprotected sex. In addition, the term sterile was often confused with infertile.

The next set of questions addressed the risk factors for infertility. Several identified factors and common myths were then read towards the participants and they would decide whether certain factors were causing infertility. The similarities and contrasts between both groups can be seen in Table 2 .

The knowledge for both groups regarding the medical risk factors for infertility were poor. Less than half participants could identify all medically related risk factors of infertility. Both groups were also unaware of social and lifestyle factors of infertility. Roughly half participants were misled in the danger of smoking, obesity, and psychological stress (as can be seen in Table. 2).

There was an interesting finding in the knowledge regarding the use of medically approved birth control on long term infertility. In Jakarta, more people believed that birth control would not affect long-term fertility. More than one third (39.1\%) of participants in Jakarta still identify the use of Oral Contraceptive Pill (OCP) to cause long-term infertility, and more so (52.1\%) in East Sumba. Similar trend could be observed in the perceived effect of Intrauterine Device (IUD) use. More than one fourth $(27.2 \%)$ of participants in Jakarta and roughly half participants (47.1\%) in East Sumba thought that IUD causes infertility.

One major difference was found with regards to supernatural belief in fertility. In East Sumba, more than 50\% of the participants had superstition that mythical or black magic contribute to infertility, while only roughly $5 \%$ of participants agreed in Jakarta.
Table 1 Demography of interviewed individuals

\begin{tabular}{|c|c|c|c|c|}
\hline \multirow[t]{2}{*}{ Variable } & \multicolumn{2}{|c|}{ Jakarta } & \multicolumn{2}{|c|}{ East Sumba } \\
\hline & $\mathrm{N}$ & $\%$ & $\mathrm{~N}$ & $\%$ \\
\hline \multicolumn{5}{|l|}{ Sex } \\
\hline Male & 64 & $42.4 \%$ & 53 & $43.8 \%$ \\
\hline \multicolumn{5}{|l|}{ Age } \\
\hline $18-20$ & 3 & $2.0 \%$ & 2 & $1.7 \%$ \\
\hline $20-29$ & 129 & $85.4 \%$ & 33 & $27.3 \%$ \\
\hline $30-39$ & 13 & $8.6 \%$ & 43 & $35.5 \%$ \\
\hline $40-49$ & 4 & $2.6 \%$ & 22 & $18.2 \%$ \\
\hline $50-59$ & 1 & $0.7 \%$ & 11 & $9.1 \%$ \\
\hline$>59$ & 1 & $0.7 \%$ & 10 & $8.3 \%$ \\
\hline \multicolumn{5}{|l|}{ Marital Status } \\
\hline Unmarried & 116 & $76.8 \%$ & 16 & $13.2 \%$ \\
\hline Married & 34 & $22.5 \%$ & 100 & $82.6 \%$ \\
\hline Divorced & 1 & $0.7 \%$ & 1 & $0.8 \%$ \\
\hline Widow/er & 0 & $0.0 \%$ & 4 & $3.3 \%$ \\
\hline \multicolumn{5}{|l|}{ Education } \\
\hline None & 0 & $0.0 \%$ & 9 & $7.4 \%$ \\
\hline Primary & 0 & $0.0 \%$ & 26 & $21.5 \%$ \\
\hline Secondary & 2 & $1.3 \%$ & 19 & $15.7 \%$ \\
\hline High school & 24 & $15.9 \%$ & 41 & $33.9 \%$ \\
\hline Diploma & 7 & $4.6 \%$ & 8 & $6.6 \%$ \\
\hline Bachelor & 118 & $78.1 \%$ & 18 & $14.9 \%$ \\
\hline \multicolumn{5}{|l|}{ Religion } \\
\hline Muslim & 114 & $75.5 \%$ & 36 & $29.8 \%$ \\
\hline Christian & 17 & $11.3 \%$ & 58 & $47.9 \%$ \\
\hline Catholic & 12 & $7.9 \%$ & 26 & $21.5 \%$ \\
\hline Buddha & 3 & $2.0 \%$ & 0 & $0.0 \%$ \\
\hline Hindu & 0 & $0.0 \%$ & 0 & $0.0 \%$ \\
\hline Others & 5 & $3.3 \%$ & 1 & $0.8 \%$ \\
\hline
\end{tabular}

Overall, when comparing the data qualitatively, there was a higher percentage of East Sumba participants who were misinformed. In East Sumba, more participants seemed to view contraception (OCP and IUD) as a mean to permanently reduce infertility when compared to actual medically related risk factors (Menstrual disturbance, Problem in uterine passage, and history of genital tract infection). This trend was not observed among participants in Jakarta who seemed to be lacking information rather than misinformed regarding causes and risk factors of infertility.

\section{Attitude towards infertility}

Half of participants in both groups identified infertility not as a disease (56.3 and $49.6 \%$ among participants in Jakarta and East Sumba respectively). However, upon given the next question regarding the necessity for treatments for 
Table 2 Knowledge on risk factors of infertility

\begin{tabular}{|c|c|c|c|c|}
\hline \multirow[t]{2}{*}{ Knowledge on risk factors of infertility } & \multicolumn{2}{|c|}{ Jakarta } & \multicolumn{2}{|c|}{ East Sumba } \\
\hline & $\bar{N}$ & $\%$ & $\mathrm{~N}$ & $\%$ \\
\hline Menstrual disturbance & 82 & $54.3 \%$ & 59 & $48.8 \%$ \\
\hline Problem in uterine passage & 116 & $76.8 \%$ & 68 & $56.2 \%$ \\
\hline History of genital tract infection in females & 63 & $41.7 \%$ & 48 & $39.7 \%$ \\
\hline History of genital tract infection in males & 57 & $37.7 \%$ & 43 & $35.5 \%$ \\
\hline Smoking & 97 & $64.2 \%$ & 73 & $60.3 \%$ \\
\hline Obesity & 72 & $47.7 \%$ & 61 & $50.4 \%$ \\
\hline Psychological stress & 113 & $74.8 \%$ & 78 & $64.5 \%$ \\
\hline History of Oral Contraceptive Pills & 59 & $39.1 \%$ & 63 & $52.1 \%$ \\
\hline History of Intrauterine device & 41 & $27.2 \%$ & 57 & $47.1 \%$ \\
\hline Mythical or supernatural causes & 7 & $4.6 \%$ & 63 & $52.1 \%$ \\
\hline Black magic & 9 & $6.0 \%$ & 64 & $52.9 \%$ \\
\hline Regular exercise & 6 & $4.0 \%$ & 22 & $18.2 \%$ \\
\hline
\end{tabular}

infertile couple, majority of participants would agree. Most participants in Jakarta agreed to treat infertile couple, while one in five participants considered that infertility does not need to be treated in East Sumba (96.0\% vs. 81.8\%). Among those believing that infertility does not need to be treated, many states that infertility is something congenital and already destined from the beginning by God or genetic.

The next question assumed that an infertile couple would like to be investigated and participants were asked about who should be examined first. Majority of the participants in Jakarta answered that both husband and wife should be investigated. One third of participants in East Sumba thought that women should be investigated first.

Later question addressed the possibility of secondary infertility. Participants in Jakarta were less well informed with only one third acknowledges secondary infertility, while more than half in East Sumba claimed that it was possible to become infertile even after conceiving (36.4\% vs $57.0 \%)$.

The last question assessed where the participants would seek treatment for infertile couple. They were given options to consult medical doctors, witch doctors, selfmedicate, or seek other alternative therapies. The differences between two groups were distinct. While only one participant in Jakarta would like to seek other help before consulting medical doctors, $36.4 \%$ of participants in East Sumba preferred to seek help from other alternatives first. The most popular alternative therapy was traditional massage in the lower abdominal and lower back area.

Given failure of the preferred initial treatment, 49.0\% of participants in Jakarta and 34,7\% of participants in East Sumba were still confident to consult another medical doctor. However, there were some participants in East Sumba that would not seek help from medical doctors $(11.6 \%)$ even when alternative therapies had failed.
The participants claimed that this was due to unavailability of medical doctors and perceived incompetence of medical doctors in treating infertility (Table 3).

\section{Treatment options}

There were more participants approving divorce in the event of infertility in East Sumba (27.3\% for infertile female and $16.5 \%$ for infertile male). In contrast, participants in Jakarta seemed to be more resilient in their marriage when encountering infertility, with less participants who approved divorce $(4.0 \%$ for infertile female and $7.3 \%$ for infertile male).

Similar trend was observed for approving the husbands to remarry in the event of infertile female: 41.3 and $17.2 \%$ of participants in East Sumba and Jakarta respectively. However, in the case of infertile male, both groups seemed to be less approving for the wives to remarry: 18.2 and $11.9 \%$ of participants in East Sumba and Jakarta respectively.

In addition, both groups claimed that the wives were being blamed by the society in the event of infertility. Majority of the participants in Jakarta (59.6\%) claimed that neither can be blamed, while only roughly one third of participants (38.0\%) in East Sumba agreed. Among the participants claiming that the society was blaming the infertile couples, 34.7 and $23.8 \%$ in East Sumba and Jakarta claim that the wives were the victim. In contrast, less participants claimed that the husbands were the victim: 7.4 and $1.3 \%$ in East Sumba and Jakarta respectively.

Table 3 Attitude towards infertility

\begin{tabular}{|c|c|c|c|c|}
\hline \multirow{2}{*}{$\begin{array}{l}\text { Attitude } \\
\text { towards } \\
\text { infertility }\end{array}$} & \multicolumn{2}{|c|}{ Jakarta } & \multicolumn{2}{|c|}{ East Sumba } \\
\hline & $\mathrm{N}$ & $\%$ & $\mathrm{~N}$ & $\%$ \\
\hline \multicolumn{5}{|c|}{ Infertility regarded as a disease } \\
\hline Yes & 85 & $56.3 \%$ & 60 & $49.6 \%$ \\
\hline \multicolumn{5}{|c|}{ Treatment is needed for infertile couple } \\
\hline Yes & 145 & $96.0 \%$ & 99 & $81.8 \%$ \\
\hline \multicolumn{5}{|c|}{ Who should be first investigated among infertile couples } \\
\hline Husband & 3 & $2.0 \%$ & 14 & $11.6 \%$ \\
\hline Wife & 7 & $4.6 \%$ & 40 & $33.1 \%$ \\
\hline Both & 141 & $93.4 \%$ & 67 & $55.4 \%$ \\
\hline \multicolumn{5}{|c|}{ Possibility of secondary infertility } \\
\hline Yes & 55 & $36.4 \%$ & 69 & $57.0 \%$ \\
\hline \multicolumn{5}{|c|}{ First preference for treatment } \\
\hline Doctors & 150 & $99.3 \%$ & 77 & $63.6 \%$ \\
\hline Others & 1 & $0.7 \%$ & 44 & $36.4 \%$ \\
\hline \multicolumn{5}{|c|}{ Secondary preference for treatment } \\
\hline Doctors & 74 & $49.0 \%$ & 42 & $34.7 \%$ \\
\hline Others & 77 & $51.0 \%$ & 79 & $65.3 \%$ \\
\hline
\end{tabular}


Adoption was favorable in both groups and viewed as a good solution for infertile couples. Most participants would approve adoption as long as full consent from both biological parents and the infertile couple could be achieved (83.4 and $84.3 \%$ in Jakarta and East Sumba respectively).

Preceding the next question, a little explanation on "test-tube baby" was given due to lack of knowledge on the subject. It was defined as taking the sperm and egg of the infertile couple, followed conducting fertilization outside the body, and transferring the embryo back to the biological mother so that she could bear child normally. The use of surrogate mother for the procedure was not the intention of this question. Majority of the participants in both groups seemed to be able to accept the idea (82.1 and $74.4 \%$ in Jakarta and East Sumba respectively). Those participants disagreeing to such procedure would claim that it was not natural and as though humans were playing God. However, most participants would accept the use of fertility enhancing drug (92.1 and $96.7 \%$ in Jakarta and East Sumba respectively). The small percentage who disagreed would claim that it was unnecessary to treat infertility altogether because if it was the will of God that a couple is infertile (Table 4).

\section{Discussion}

Despite diverse demography of participants in Jakarta and Sumba, there is low level of knowledge towards fertility. Regardless of difference in age, level of education, marital status, and religion, participants from both groups have low knowledge about infertility. The higher level of education nor better access of information in Jakarta does not prevent naivety towards risk factors of infertility. This shows that participants are unaware how to prevent infertility and when or where to seek help should they are infertile. This tendency is also observed globally in a survey in the World Fertility Awareness Month [10]. This may be explained by the lack of basic reproductive health education in Indonesia.

Furthermore, the participants are not merely uninformed about infertility, but rather they have erroneous knowledge. One interesting finding is that roughly half of participants do not believe the advertisement and medical professionals' advice on the danger of smoking that may harm fertility [2]. Many participants argue that they know many who smokes yet having no problem to conceive. The same trend can be observed in obesity and psychological stress as modifiable risk factors. These lifestyle risk factors are regarded of less importance in influencing one's fertility. This suggest that in cases of infertility, participants would often overlook these modifiable risk factors.

Paradoxically, advices by medical professionals on the use of contraceptive pills and intrauterine device to withheld
Table 4 Options for infertile couples

\begin{tabular}{|c|c|c|c|c|}
\hline \multirow{2}{*}{$\begin{array}{l}\text { Options for } \\
\text { infertile } \\
\text { couples }\end{array}$} & \multicolumn{2}{|c|}{ Jakarta } & \multicolumn{2}{|c|}{ East Sumba } \\
\hline & $\mathrm{N}$ & $\%$ & $\mathrm{~N}$ & $\%$ \\
\hline \multicolumn{5}{|c|}{ Infertile female: divorce } \\
\hline Yes & 6 & $4.0 \%$ & 33 & $27.3 \%$ \\
\hline \multicolumn{5}{|c|}{ Infertile female: remarry } \\
\hline Yes & 26 & $17.2 \%$ & 50 & $41.3 \%$ \\
\hline \multicolumn{5}{|c|}{ Infertile male: divorce } \\
\hline Yes & 11 & $7.3 \%$ & 20 & $16.5 \%$ \\
\hline \multicolumn{5}{|c|}{ Infertile male: remarry } \\
\hline Yes & 18 & $11.9 \%$ & 22 & $18.2 \%$ \\
\hline \multicolumn{5}{|c|}{ Blamed by the society } \\
\hline Husband & 2 & $1.3 \%$ & 9 & $7.4 \%$ \\
\hline Wife & 36 & $23.8 \%$ & 42 & $34.7 \%$ \\
\hline Both & 23 & $15.2 \%$ & 24 & $19.8 \%$ \\
\hline Neither & 90 & $59.6 \%$ & 46 & $38.0 \%$ \\
\hline \multicolumn{5}{|l|}{ Adoption } \\
\hline Yes & 126 & $83.4 \%$ & 102 & $84.3 \%$ \\
\hline \multicolumn{5}{|c|}{ Use of Test-tube Baby } \\
\hline Agreeable & 124 & $82.1 \%$ & 90 & $74.4 \%$ \\
\hline \multicolumn{5}{|c|}{ Use of Fertility drug } \\
\hline Yes & 139 & $92.1 \%$ & 117 & $96.7 \%$ \\
\hline
\end{tabular}

pregnancy is often believed to permanently decrease fertility. This finding suggests lack of knowledge on how contraception works as participants may falsely blame contraception for infertility. This lack of understanding will lead to several socio-economic problems associated with averting birth control: overpopulation and poverty [11]. A survey has shown that $15.5 \%$ of married reproductive age women in Indonesia has never undergone any contraception, despite enthusiastic campaign by the Government [12]. This is contrary to a survey by Mac Dougall et al. on 61 women who visited fertility clinics in the USA, in which fertility was overestimated, hence $23 \%$ stressed lifelong pregnancy control using contraceptive methods. While our study subjects in general fear of fertility decline following contraceptive use, subjects in Mac Dougall et al. study perceived the need to "control" pregnancy in fear of unexpected pregnancy following cessation of contraception [13].

Another erroneous perception would be assuming that infertility is not a disease. The participants tend to view infertility as something absolute or congenital. If anything, infertility is often associated as the will of higher being. Thus, it becomes a habit among them to seek more spiritual approach to solve infertility. This view is complementary to their obliviousness towards secondary infertility. Participants tend to think that once a couple can conceive, it is simply about time and other superstitious factors that will conceive again. The unfavorable 
outcome from this misperception would lead to couples not seeking treatment.

Level of trust towards medical professionals in East Sumba, which is rural area, is surprisingly low. Rather, some of the participants show blind faiths towards alternative healing. Although almost all participants have a religion, many also believes in the power black magic and shaman. This is consistent with previous findings on low level of knowledge on infertility. It then becomes a common practice to visit the shamans before medical professionals when faced with infertility. A prospective study on urban population in the US by Smith et al. identified $45 \%$ of couples seeking fertility care had tried alternative fertility treatments such as acupuncture, herbal, body work and meditation [14]. This means that alternative treatment across various socio-economic and educational background is always a considerable option.

The problem is even greater in our society in which our finding revealed some of the participants would rather not visit medical professionals at all. This might be explained by higher availability of shamans compared to doctors, also perpetuated by gap in availability of medical amenities and trained medical doctors in Jakarta and East Sumba. This is consistent with previous statement regarding unequal availability of medical competence and technologies across Indonesia [2]. Eventually, several members of the community, especially those living in rural areas have inadequate fertility treatment.

The outcome of infertility is indeed devastating. Victimization towards infertile couples occurs regardless of religious beliefs and socio-economical background. Although not allowed by religions in Indonesia, the pressure from the society towards infertile couple may consequently lead to divorce. Despite equal contribution of male and female factors to infertility cases, women seem to suffer more from the disease both in terms of social stigma and divorce. The similar trend can be observed in three different countries: Saudi [15], Iran and Pakistan [4]. This may be due to lack of knowledge regarding the medical causes and infertility treatment options observed among developing countries.

Adoption might offer a better solution than divorce. Most participants in both groups would agree to adopt a child for infertile couples. From the participants response we can infer that people think married couple should have child, regardless of bearing their own or adopting one. However, adoption has not become a common practice. The data in Indonesia is lacking, but in Karachi, capital city of Pakistan, only 6\% of 400 infertile couples have adopted a child [5]. There seems to be more benefit for infertile couples to adopt a child, but it has high complexity and remains debatable from psychological perspectives [16]. The seemingly low trend of infertile couple opting for adoption may suggest that particularly for childless couple, adopting a child is inferior and cannot replace the feeling of having one on their own [17].

Assisted Reproductive Technology (ART) might offer a better solution for infertile couples [18]. The term of "test-tube baby" is often unfamiliar among the participants. During our survey we observed the common trend of fear of the unknown and assumption of playing God caused, the participants to be reluctant towards the idea. This was alleviated when short explanation of the procedure is explained to the participants. Thus, in the result we can see most participants agree towards the use ART to combat infertility. Similar findings has been observed in the presence of gap due to lack of knowledge between the potential and willingness of ART procedures [19]. This suggests that better understanding towards infertility and how ART works will improve its acceptance in both urban and rural regions.

The mean of understanding fertility seems to occur through mouth-to-mouth conversations between laymen in Indonesia. This explains why erroneous information tends to spread in the community. Similar problem was also reported by Mac Dougall in which incorrect information spread among the subjects mostly through friends, misleading media reports, and even physicians in the United States [13].

Despite our attempt to provide data representing urban and rural population in Indonesia, our study has its limitations in terms of its representativeness. Total sampling method used to recruit respondents may lead to poor representation of the population. Although participants in Jakarta were recruited in both primary healthcare center and tertiary care hospital, heterogeneity is still lacking. Subjects in Jakarta greatly represent under 30-year-old age group (87.4\%), unmarried (76.8\%), and higher educated subjects. This may cause the researchers to overlook the subset of subjects who were married, older and with lower educational background. We also did not incorporate income groups in our questionnaire. Previous studies by Nachtigall et al. have demonstrated that decision to seek fertility treatment, more specifically ART that is notoriously expensive is highly influenced by economical background [20].

\section{Conclusions}

Despite difference in demography between the two groups, similar views towards infertility and its treatment option can be observed. Ultimately, both groups have low level of knowledge, negative attitude, and false perception towards infertility. Devastating social outcome such as divorce is often deemed acceptable in infertile couple. Short information on infertility and its treatment has been shown to increase acceptability towards medical interventions. This study can hopefully be used as 
ground for future fertility education with regards to cultural competence.

\section{Abbreviations}

ART: Assisted Reproductive Technology; IUD: Intrauterine Device; OCP: Oral Contraceptive Pills

\section{Acknowledgements}

Dr. Marcella Burhan, dr. Kimberly Batanghari, dr. Chairunnisya Natasya, and dr. Paulus Jonathan have helped to interview and collected the data from participants.

\section{Authors' contributions}

AKH has guided and supervised the authors in the design and writing of the manuscript. VPAS has designed the study, collected and analyzed the data, and wrote the manuscript. SW has helped with the design of the study, collected and analyzed the data. All authors read and approved the final manuscript.

\section{Funding}

The research is self-funded by the authors.

\section{Availability of data and materials}

The datasets generated and/or analyzed during the current study are available in the google sheets repository:

https://docs.google.com/spreadsheets/d/13OqZYqPED5

XZhrHVqct9Hf8WMoK8T3kj6DJJYSLrOrE/edit.

The datasets generated and/or analyzed during the current study are not publicly available due to ethical concern of personal information regarding socio-economic status and religious beliefs but are available from the corresponding author on reasonable request.

\section{Ethics approval and consent to participate}

This study been reviewed and given ethical approval from Ethics Committee of the Faculty of Medicine, Universitas Indonesia. Reference Number: 0634/ UN2.F1/ETIK.

\section{Consent for publication}

Not applicable.

\section{Competing interests}

The authors declare that they have no competing interests.

Received: 7 August 2018 Accepted: 13 August 2019

Published online: 19 August 2019

\section{References}

1. World Health Organization. Sexual and reproduction health: infertility definitions and terminology. http://www.who.int/reproductivehealth/topics/ infertility/definitions/en. Accessed 3 Jul 2018.

2. Hestiantoro A, Wiweko B, Pratama G, Dwiyanarsi Y. Konsensus Penanganan Infertilitas. BAB VI: Penanganan Kasus Berdasarkan Kompetensi Klinis. Indonesia; 2013

3. Callahan TL, Caughey AB. Infertility and assisted reproductive technologies. Blueprints Obstetrics and Gynecology. 7th ed. Philadelphia: Wolters Kluwer Health; 2018. p. 883-920

4. Ali S, Sophie R, Imam AM, Khan Fl, Ali SF, Shaikh A, Farid-ul-Hasnain S. Knowledge, perceptions and myths regarding infertility among selected adult population in Pakistan: a cross-sectional study. BMC Public Health. $2011 ; 11: 760$

5. Ali TS, Sami N. Adoption practices among couples with secondary infertility in Karachi: a triangulation study design. J Pak Med Assoc. 2007;57(2):55-9.

6. Amiri M, Khosravi A, Chaman R, Sadeghi Z, Raei M, Jahanitiji MA, Mehrabian F. Social consequences of infertility on families in Iran. Global J Health Sci. 2016;8(5):89-94

7. Deyhoul N, Mohamaddoost T, Hosseini M. Infertility-Related Risk Factors: A Systematic Review. Int J Womens Health. 2017;5(1):24-9.

8. Adashi EY, Cohen J, Hamberger L, Jones HW Jr, de Kretser DM, Lunenfeld B, Rosenwaks Z, Van Steirteghem A. Public perception on infertility and its treatment: an international survey. The Bertarelli Foundation Scientific Board. Hum Reprod. 2000;15(2):330-4.
9. Boivin J, Bunting L. Knowledge about infertility risk factors, fertility myths and illusory benefits of healthy habits in young people. Hum Reprod. 2008; 23(8):1858-64.

10. World fertility awareness month. What you never know about fertility. 2006.

11. Birdsall N, Sinding S. Population matters: demographic change, economic growth, and poverty in the developing world. New York: Oxford University Press; 2003.

12. Badan Penelitian Dan Pengembangan Kesehatan Kementerian Kesehatan RI. Riset Kesehatan Dasar. Riskesdas 2013.

13. Mac Dougall K, Beyene $Y$, Nachtigall RD. Age shock: misperceptions of the impact of age on fertility before and after IVF in women who conceived after age 40. Hum Reprod. 2013:28(2):350-6.

14. Smith JF, Eisenberg ML, Millstein SG, Nachtigall RD, Shindel AW, Wing H, et al. The use of complementary and alternative fertility treatment in couples seeking fertility care: data from a prospective cohort in the United States. Fertil Steril. 2010;93(7):2169-74.

15. Abolfotouh MA, Alabdrabalnabi AA, Albacker RB, Al-Jughaiman UA, Hassan SN. Knowledge, attitude and practices of infertility among Saudi couples. Int J Gen Med. 2013;6:563-73.

16. Child Welfare Information Gateway. Adoption disruption and dissolution. Numbers and trends. 2012. Available online at https://www.childwelfare. gov/pubs/s_disrup.cfm

17. Zamostny KP, Wiley MOL, O'Brien KM, Lee RM, Baden AL. Advancing knowledge about adoption for counseling psychologists. Couns Psychol. 2003:31(6):647-50. https://doi.org/10.1177/0011000003258082

18. Ying LY, Wu LH, Loke AY. The experience of Chinese couples undergoing in vitro fertilization treatment: perception of the treatment process and partner support. PLoS One. 2015;10(10):e0139691.

19. Meissner C, Schippert C, Versen-HÖynck FV. Awareness, knowledge, and perceptions of infertility, fertility assessment, and assisted reproductive technologies in the era of oocyte freezing among female and male university students. J Assist Reprod Genet. 2016;33(6):719-29. https://doi. org/10.1007/s10815-016-0717-1

20. Nachtigall RD. International disparities in access to infertility services. Fertil Steril. 2006;85(4):871-5

\section{Publisher's Note}

Springer Nature remains neutral with regard to jurisdictional claims in published maps and institutional affiliations.
Ready to submit your research? Choose BMC and benefit from:

- fast, convenient online submission

- thorough peer review by experienced researchers in your field

- rapid publication on acceptance

- support for research data, including large and complex data types

- gold Open Access which fosters wider collaboration and increased citations

- maximum visibility for your research: over $100 \mathrm{M}$ website views per year

At BMC, research is always in progress.

Learn more biomedcentral.com/submissions 